CHAPTER 3

\title{
Heritage, Openness and the Commons in Urban Environments: Some Thoughts on the Archaeological Parks of Philopappos Hill and Plato's Academy in Athens
}

\author{
Despina Catapoti, Ioulia Skounaki and \\ Georgia Gkoumopoulou
}

Until recently, the dominant management model of archaeological sites in Greece largely drew upon a logic of enframing (Thomas 2004: 79; see also DíazAndreu \& Champion 1996; Dietler 1994; Olsen 2012), which understood the past as "gone" and "completed", a temporal entity in other words, whose closure and finitude needed to be guaranteed through physical demarcation (Olsen, 2012: 215). We shall call this "the enclosure model", for in essence, it sought to isolate monuments from the sphere of the everyday. The tendency to spatially distinguish the past from the present has its roots in modernity, particularly the $19^{\text {th }}$ century: at the time, prominent archaeological sites across the Mediterranean were marked out (and henceforth rendered "visible") as loci of exclusive membership (i.e. products of archaeological activity, arenas of intellectual/ scientific discourse) but above all, as representational spaces of collective appeal, accommodating both nationalist and colonialist narratives (cf. Catapoti 2013; Catapoti \& Relaki 2013; Hamilakis 2007; Plantzos 2014: 104, 260-272;

How to cite this book chapter:

Catapoti, D. Skounaki, I. and Gkoumopoulou, G. 2020. Heritage, Openness and the Commons in Urban Environments: Some Thoughts on the Archaeological Parks of Philopappos Hill and Plato's Academy in Athens. In Lekakis, S. (ed.) Cultural Heritage in the Realm of the Commons: Conversations on the Case of Greece. Pp. 67-94. London: Ubiquity Press. DOI: https://doi.org/10.5334/bcj.e. License: CC-BY 
Sack 1986; Smith 2008; Thomas 2004; Vavouranakis 2018: 23-25; White 1973; Wylie 2005; Yalouri 2001). On the one hand, the archaeological site was perceived as a bounded and protected area, in which the public could only enter under certain conditions stipulated by the relevant authorities (Carman 2005; Hamilakis 2007: 17; Smith 2008; Buck Sutton \& Stroulia 2010: 3). The boundaries set between the public and past material remains, on the other hand, moved beyond the spatial to also encapsulate the ideological and the conceptual, with both the state and the scientific community assuming a higher-order role, that of the custodian of the past, its meanings, value and symbolisms (Appadurai 2008; Catapoti 2013: 263-266; Hall 2008: 220; Nicholas \& Hollowell 2007: 60; Pels 1997; Smith 2004: 68-74, 2008: 62-3).

The Greek legal framework stipulates that all monuments dating up to 1453 are the property of the State, not subject to exchange and long-term private use (Law 3028/2002). ${ }^{13}$ In practice, this should not be taken to imply that the Greek Archaeological Service fences off every archaeological excavation or monument in the country, thereby cancelling out any other potential private or public use. It does, however, set out that state authorities have the final say in every potential use of such monuments. What stands out as a paradox here is that although experts (i.e. archaeologists, conservators etc.) and the public in Greece share a broad consensus with regard to the value of archaeological heritage - defending a standard "protocol" for its protection, study and promotion - the long-established state monopoly on archaeological monuments and the "overcentralisation of the administrative system" (Tziotas 2015: 49) is systematically accused of clientelism, opportunism and favouritism (Alexopoulos \& Fouseki 2013; Hamilakis 2007: 37; Tziotas 2015: 49), while leaving little or no room for the cultivation of bottom-up processes of participation, dialogue and negotiation (Stroulia \& Buck Sutton 2010). As a result, archaeology is commonly referred to as "the State's bureaucratic face" (Fotiadis 2010: 454) and often results in feelings of social distrust as well as a proliferation of conspiracy theories against the Archaeological Service.

13 " $[\mathrm{A}] \mathrm{ll}$ antiquities belong to the state and their administration is the duty of the Ministry of Culture and its dedicated Archaeological Resource Management (ARM) service, the so-called General Directorate of Antiquities and Cultural Heritage, and informally dubbed as the "Archaeological Service", namely the body of state archaeologists in Greece" (Vavouranakis 2018: 23). Vavouranakis has argued that a "strong" Archaeological Resource Management has always been necessary for the Greek State largely due to the fact that the latter needs "to reclaim illicitly circulating antiquities" (ibid: 24). It is for this reason perhaps that "the ownership of monuments is a standard feature of the Greek archaeological legislation. Law 2646, which came into effect in 1899, its codification Law 5351, which substituted it in 1932, and the current Law 3028, which replaced the previous laws in 2002, all state that all antiquities are owned by the state" (ibid); See also Lekakis this volume. 
As a result of this, archaeologists in Greece display a schizoid socio-political profile, acting as both enemies and guardians of the past (cf. Plantzos 2018: 106). Thus, for instance, in certain cases the Service is heavily scrutinized (as biased, nationalist, bureaucratic, outdated) for its insistence on the spatial demarcation and sacralisation of antiquities, whereas in others, it is the Service that is called upon to protect these vulnerable and exhaustible resources from looting, abuse or overuse. Equally interesting is the fact that although the "enclosure model" has received much criticism for supporting the activation and harvesting of the economic value of heritage resources (in other words, their transformation into a tourist product) (Catapoti 2013: 270; Hamilakis \& Duke 2007; Holtorf 2005; Kehoe 2007; Lowenthal 2002; Silberman 2007: 179-182; Walsh 1992), this is a strategy also frequently supported by local communities, who recognise the opportunity for economic profit that the existence of an organised archaeological site in their area affords ( $c f$. Bianchi 2003; Boissevain 1996; Galani-Moutafi 2002; Urry 1990; Zarkia 1996).

Over the last two decades, however, the situation described above regarding heritage management in Greece has undergone significant transformations. Currently, a plethora of initiatives are promoting the idea of opening up sites and monuments to a wider audience. Catapoti (2013) has argued that "openness" refers to a wide variety of practices and strands such as the use of monuments and archaeological sites outside of opening hours for the organization of cultural events and performances; calls for the reuse of ancient and historical monuments (i.e. ancient theatres); increased participation of non-specialist groups and volunteers in excavation projects; the promotion of archaeological experience and tourism packages; the growing number of archaeological parks and ecomuseums; programmes and funding devoted to the visual and functional unification of archaeological sites and monuments in urban centres; the increasing emphasis on urban walks and heritage walking tours; the advancement and development of digital applications in archaeology and cultural heritage (i.e. open access digital resources, VR and AR reconstructions and tours, digital apps for museum visits, increasing museum presence in social media platforms and digital marketing). Interestingly, in certain cases, these initiatives are spearheaded by the Archaeological Service itself in an obvious attempt to move beyond its customary modus operandi concerning heritage management. Equally significant is the fact that, quite often, the call for openness is also supported by urban social movements or specific stakeholder groups (e.g. parent groups) - with the aim of widening the availability of leisure spaces and educational facilities within the city (green areas and parks, spaces for children, physical exercise etc.). In other cases, these efforts mask implicit or explicit claims for further touristic development, as is also the situation in most rural parts of Greece.

In recent years, what has been emphasized by several scholars ${ }^{14}$ is the fact that the emergent pluralism and cornucopia of approaches in the heritage

${ }^{14}$ See Catapoti 2013 for a review of the literature. 
sector does not merely form part of a wider theoretical regime that favours openness; what is equally noteworthy is that this regime has developed the ability to fully embrace seemingly opposing ideological agendas, ranging from neoliberal marketing strategies to small-scale, non-institutionalized political action (Antoniadou et al 2018). Jameson (1984) eloquently demonstrated how this pluralistic logic constitutes the backbone of late capitalism, supporting social fragmentation, subjectivity, fluidity of all boundaries (spatial, temporal, social, political, and even corporeal), individuality and the self, the constant reinvention of all aforementioned categories, and with them, a constant reinvention of consumer goods as markers of identity and the self (Harvey 1989; see also Anderson 1998; Catapoti 2013: 269-70). In view of the above, it becomes readily apparent how the continuous renewal of the past and by extension, the creation of a steadily growing heritage surplus, become totally attuned with the idea of openness and contribute to its very sustenance. What also becomes increasingly crystallised, however, as Frank rightly stresses (2015: 25), is that this process of "breaking down" boundaries simultaneously leads to the democratisation as well as the commercialisation of the past.

An immediate consequence of these developments has been on the one hand, that the dearth of quantitative and qualitative data described above is accompanied by an obvious paucity of criteria for evaluating the ways in which the steadily increasing body of cultural spaces is managed, leading to an absence of critical, coherent, and substantiated suggestions for the preservation or reassessment of cemented practices. Despite this lack of systematization on the other hand, what is particularly noteworthy is that in recent years, a new concept appears to be gaining ground (and popularity) as an alternative against the polarized distinction between "closure" and "openness" and this is the concept of the "commons":

\begin{abstract}
"We live in the midst of a social and economic crisis, one of the worst in capitalism's history; at the same time the environmental crisis, according to the predictions of the vast majority of scientists, is approaching catastrophe. Neither states nor markets seem able to offer solutions. On the contrary, many believe that they are the main sources of these crises. It is in this context that talks of - and social movements for - commons have become not only increasingly commonplace, but also increasingly relevant" (De Angelis \& Harvie 2014: 280).
\end{abstract}

In thinking about what commons are, an obvious point of departure is that they refer to shared resources that are neither public nor private. Sharing is a parameter of crucial importance here, for it implies a form of ownership (or responsibility) that is constituted through collective use and negotiation rather than as a predetermined condition (e.g. a property relation). Although initially, the commons were mainly linked with the study and improvement of the management of natural, eco-social systems and common pool resources, currently 
they embrace other sociopolitical fields, including urban contexts (for an overview of urban commons literature $c f$. Parker and Johansson 2011). From as far back as the early stages of the $20^{\text {th }}$ century, important thinkers like Georg Simmel (1903/1971) and Louis Wirth (1938) pointed out that in urban contexts, public space exhibits an unparalleled degree of heterogeneity and density and that as such it constitutes "a place where modern society as a market-mediated and state-protected association of strangers could first be experienced as a new social form" (Frank 2015: 22, our emphasis). In light of the above and for the purposes of this paper, we wish to examine whether (and under what conditions) the notion of the urban commons could also bear relevance on an important sub-category: urban heritage. Do the principles that apply to the study of urban commons apply equally to the study of heritage? Should commons and openness in urban cultural spaces and/or heritage loci of the city be treated as synonymous, compatible, or complementary terms? Is it possible to move beyond centralised and strictly hierarchical forms of social organization (i.e. state governance) in urban heritage management, without equating open access to laisser-faire and other neoliberalist managerial formats? Last but not least, what happens in an urban context like Athens, a city whose identity is to a very large extent fuelled by its past and the materialities of that past (Hamilakis 2007; Leontis 1995; Loukaki 2008; McNeal 1991; Planztos 2011; Yalouri 2001)?

\section{A brief note on the concept of the commons}

Although we could describe the commons as an umbrella term, encompassing a wide variety of definitions, at the most basic level it refers to resources (natural and/or cultural) that are accessible to all members of a given social unit and are managed through governance mechanisms aiming at collective benefit (Caffentzis 2010; An Architektur 2010; Hardt and Negri 2009; Ostrom 1990). At the moment, the consensus is that anything may fall into the category of common resource as long as a certain social entity decides to share and manage it collectively, setting the rules through which it is accessed, used, sustained and/or reproduced (Bollier 2014: 15; An Architektur 2010; Stavrides 2016):

“The word 'commons' refers to resources for which people do not have to pay for to exercise their user and access rights within a confine of a set of institutions or rules to protect the resources from overuse by people who do not respect the resources' fragility or limits" (Jumbe 2006: 5).

According to a number of scholars, however (see Caffentzis 2005; De Angelis \& Harvie 2014), this mode of understanding is not so straightforward, but rather a definition that encapsulates a wider (and highly complex) nexus of opinions, involving even opposing political ideologies and strategies. In certain cases, for instance, we find approaches that set themselves strongly against privatization 
and yet maintain a line of thought that sees capitalism and the commons as relatively compatible:

"Many of the capabilities of a parallel adaptive system can be retained in a polycentric governance system. By polycentric, I mean a system where citizens are able to organize not just one but multiple governing authorities at differing scales... Each unit may exercise considerable independence to make and enforce rules within a circumscribed scope of authority for a specified geographical area. In a polycentric system, some units are general-purpose governments while others may be highly specialized. Self-organized resource governance systems, in such a system, may be special districts, private associations, or parts of a local government. These are nested in several levels of general-purpose governments that also provide civil, equity, as well as criminal courts" (Ostrom 1998: 27).

Another major trend that may be identified in the literature is largely based upon social dynamics (Caffentzis 2010; An Architektur 2010; De Angelis 2007; Federici 2010; Hardt and Negri 2009). At the centre of this enquiry is the idea of commoning, namely the process whereby something becomes a common resource, but at the same time the process through which a resource creates forms of social being that are collective yet not emancipatory in nature. Under this scheme, the commons is something that "is continuously being produced" (Harvey 2011: 105).

Particularly within the context of urban theory, practices of commoning become even more emphatic. What is of cardinal analytical importance in a city with reference to the triptych "resources, commoners and rules" is its fluid nature (Kornberger \& Borch 2015). Analytical focus is thus primarily laid upon substantiating the theory that the relations established between people and resources, or more specifically the conditions and social processes that create, reproduce (and even challenge) the commons, are in a constant state of flux (Harvey 2011; 2012):

"The human qualities of the city emerge from our practices in the diverse spaces of the city, even as those spaces are subject to enclosure both by private and public state ownership, as well as by social control, appropriation, and countermoves to assert what Henri Lefebvre called "the right to the city" on the part of the inhabitants. Through their daily activities and struggles, individuals and social groups create the social world of the city and, in doing so, create something common as a framework within which we all can dwell" (Harvey 2011: 103-4).

Thus, the question addressed here focuses more on architecture, namely it is a question of spatiotemporal responsivity (Kärrholm 2015: 54). This concerns the 
need for any (emerging) group or issue to go through a trial by space (ibid). As Lefebvre notes in The Production of Space (1991):

"[G]roups, classes or fractions cannot constitute themselves, or recognize one another as "subjects", unless they generate (or produce) a space. Ideas, representations or values which do not succeed in making their mark on space, and thus generating (or producing) an appropriate morphology, will lose all pith and become mere signs, resolve themselves into abstract descriptions, or mutate into fantasies (ibid: 416-17).

This shift of emphasis towards commoning and social dynamics opens up the way for a better understanding of how urban heritage, among other resources, is introduced in the discussion of the urban commons. Heritage itself, very much like the concept of the commons, cannot be perceived as a predetermined, neutral category but must be seen instead as a concept with heavy ideological, economic, social and political connotations ( $c f$. Gero n.d.; Layton 1989; Lowenthal 1985; Miller et al. 1989; Shennan 1989; Silverman 2011). Heritage is a mnemonic resource that never ceases to be under scrutiny and reconfiguration. What also goes without saying is that this condition is further complicated within the highly heterogeneous context that is the urban landscape of cities like Athens, a landscape exhibiting an even higher density of past spatiotemporal materialities, thus rendering their interpretation and use even more difficult.

But what if, on the other hand, those conflicting, asymmetrical, discontinuous forms of engagement with heritage were not considered an obstacle but a boon? What if we decided to approach the conflicting social demands and aspirations revolving around heritage as an expression of commoning, as a process of actively negotiating urban being and identity through the past, a dynamic form of exploring the mnemonic within the urban sphere? In what follows, therefore, we argue for a more rigorous and nuanced consideration of the use and management of archaeological sites in urban contexts. This will consider the relationship between openness, the commons and the transformation of urban space engendered by historically specific dynamics of heritage management strategies. To exemplify this final point, in the following sections of this chapter we will focus our attention on two case studies: Philopappos Hill and Plato's Academy Archaeological Park, both located at the centre of Athens. ${ }^{15}$ Both case studies involve spaces officially classified as archaeological sites but also as public green spaces. The dual role served by these two sites makes them

15 The fieldwork and data collection for each case study were conducted as part of a research project funded by the Research Centre for the Humanities under the topic: “The 'open' archaeological site as an alternative management model in an urban environment: Plato's Academy and Philopappos Hill". https://www.rchumanities.gr/en/catapoti-skounaki-gkoumopoulou/. Last accessed 20 November 2019. 


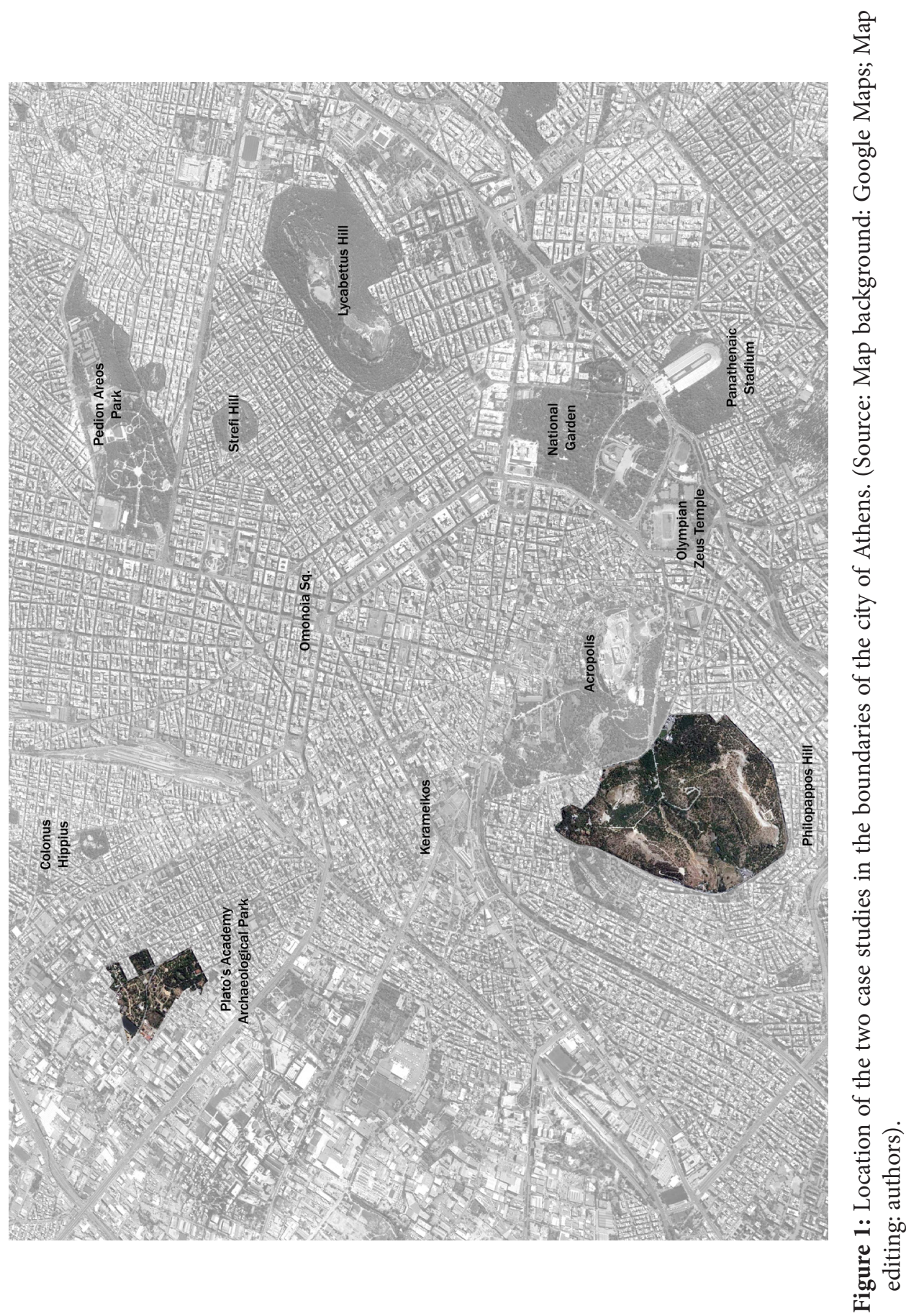


notable exceptions to the Greek rule, i.e. the 'enclosure model'. Both case studies are the 'products' of institutional management choices and top-down planning methods. At the same time, however, they play a crucial role as open green spaces, serving not only the daily needs of adjacent neighbourhoods but also operating as a broader urban imaginary, an ideal conjunction point of archaeological and environmental features/values. In fact, over the past decade, these two areas have been transformed into regions of pronounced territorial claim, not only of the state and the Archaeological Service, but also of urban movements and political groups of the surrounding neighbourhoods as well as the wider city of Athens. To date there has been no systematic investigation of (a) how either the Hill or the Park perform their twofold role (archaeological site/ urban park); (b) whether (and when) these two functions are compatible or at variance; (c) how the dynamic in situ presence of different social groups and collectivities on the Hill and the Park affects institutional decision-making and ultimately; or (d) how such forms of bottom-up political engagement contribute to the establishment of alternative models of heritage management and use within an urban setting. The final part of the paper identifies the connections established between the commons and openness at Philopappos Hill and Plato's Academy and discusses both promising elements and weak points in the conceptualization and/or pragmatism of these interconnections. How is this phenomenon to be associated with the wider forum on the commons and which approach to the commons in particular? Is this a phenomenon of only limited relevance to broader issues of cultural heritage management, or does it act as a preface for more radical developments in the future?

\section{The Archaeological Park of Plato's Academy}

The Archaeological Park of Plato's Academy is located at the centre of Athens, near the neighbourhood of Colonus, approximately $1.5 \mathrm{~km}$ north of Dipylon Gates at Kerameikos. If we were to describe the broader area of the Akademia, then this would have to include the Industrial Park (Viomihaniko Parko), comprising, in turn, notable examples of industrial architecture, flanked by historic buildings and neighbourhoods, all agents of urban memory. Along the length of the axes of Lenorman Street and Athinon Avenue (Kavalas), lies the residential area. Between the industrial and the residential sectors an intermediate zone is found, where functions would seem to overlap; meanwhile, there are also many "voids" serving the purposes of heterogeneous activities (parking lots, orchards and gardens, playgrounds etc.). Within this area we also find the Park and within it, the few archaeological remains related to Plato's famous Academy.

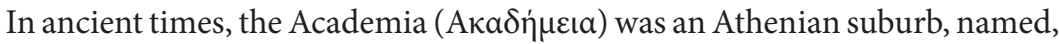
perhaps, after the mythical local hero Academos (or Ecademos). Although the area bears archaeological traces from as early as prehistoric times, it is best known for hosting (from the $4^{\text {th }}$ century BC onwards) the most famous of all 
philosophical schools of the ancient city. The Academy was set up in or beside a sacred precinct (Garden of Academos) and one of the three Gymnasia of classical Athens. It operated in the same place for several centuries and even today the location maintains its name as a tribute to the famed philosopher Plato. Around 86 BC, the Roman General Lucius Cornelius Sulla destroyed the tree-covered area to build siege engines. It appears, however, that the Academy remained a memorial and place of worship until the period of Neoplatonism $\left(5^{\text {th }}\right.$ century $\left.\mathrm{AD}\right)$ that reactivated philosophical activity in the area. The school was permanently closed down under the rule of the Byzantine emperor Justinian, during the $6^{\text {th }}$ century AD (Panagiotopoulos \& Chatziefthimiou 2017; Carouso 2013).

In the early part of the $20^{\text {th }}$ century (and mainly during the 1950s), the area experienced increased housing development while an industrial zone was also built on the outskirts of the Park. Between 1929 and 1939, the architect Panagiotis Aristophron funded excavations in the area, ${ }^{16}$ which were conducted under the supervision and the collaboration of archaeologists and archaeophiles such as K. Kourouniotes, A. Philadelpheus and J. Travlos. Among the buildings that were unearthed during fieldwork were the Gymnasium's Palaestra and the square Peristyle. Work recommenced after World War II and the Civil War, between 1956 and 1961, under the direction of Phoivos Stavropoulos and with the financial support of the Greek Archaeological Society. ${ }^{17}$ Stavropoulos' excavations brought to light the so-called House of Academos and the Sacred House. Since then, fieldwork in the area has been conducted by the Ephorate of Antiquities of West Attica (Panagiotopoulos \& Chatziefthimiou 2017).

Since its first official designation as an archaeological site in 1937, the site has continuously shrunk in size. In 1979, it was designated as an urban park (alsos) and only relatively recently, in 2000, the term Archaeological Park was introduced (see c.f. Chazapis 2015; Perpinia 2014). In the 1990s, the Archaeological Service directed an ambitious demolition programme of expropriated buildings. The areas cleared through this process underwent planting and garden landscaping by the Technical Service of the Municipality of Athens, to fulfil the vision of a fully green Plato's Academy. It is worth mentioning that, despite the extensive fencing, the Park has remained open to access with numerous entry/exit gates.

${ }^{16}$ It is worth mentioning here that Aristophron, who envisioned the revival of Plato's Academy and a 'Commons of Academies', excavated the area using his own funds and acquired (through paying compensations) a large expanse of land, much larger than hitherto known.

${ }^{17}$ The Greek Archaeological Society is an independent society founded in 1837 with the aim of encouraging the archaeological excavation, protection and exhibition of antiquities in Greece. https://www.archetai.gr. Last access 20 November 2019. 


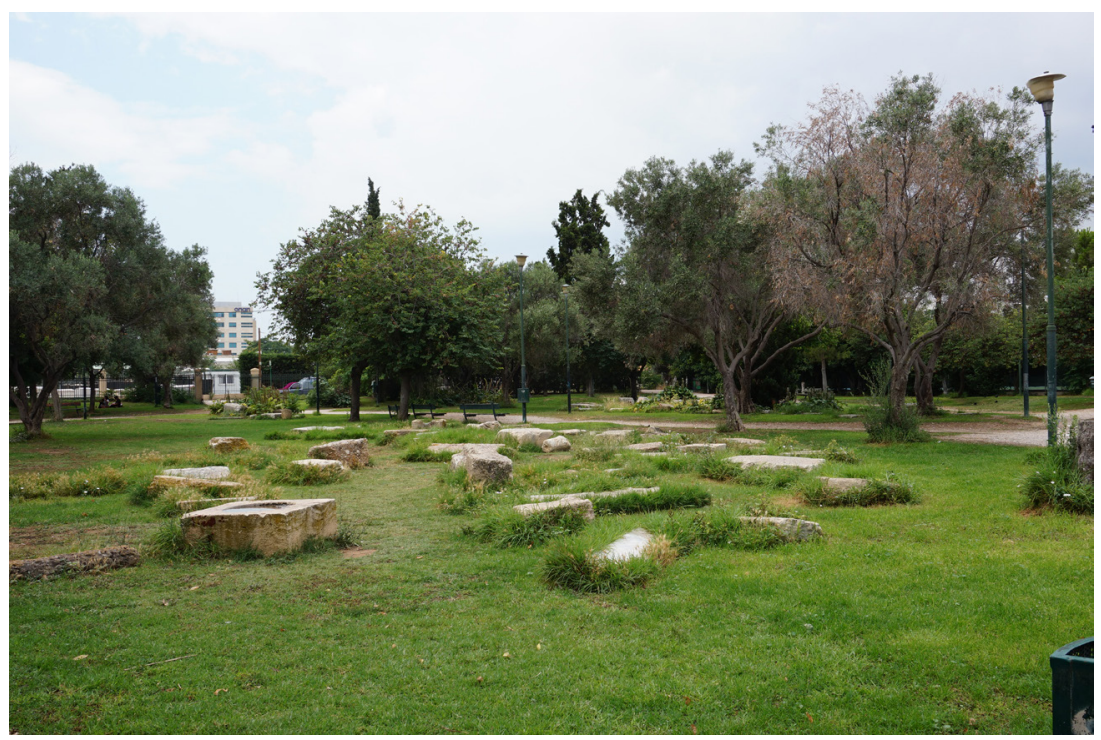

Figure 2: Archaeological finds from various excavations in the city of Athens have been placed freely inside the park to empower the site's monumental identity (Plato's Academy Park). (Source: authors).

The archaeological site constitutes an important landmark of the Athenian landscape endowed with supra-local symbolic value as noted in the first Regulatory Master Plan of Athens (RPA) (Law 1515/1985) as well as by the intention of the official authorities to include the site in the Unification Project of Archaeological Sites at the centre of Athens (UPASA) (see below). The current vision for the archaeological site and the wider area of Plato's Academy involves the creation of a "Supra-Local Centre of Cultural Activities", the Academy of Nations and the Archaeological Museum of the City of Athens, all to be achieved within the framework of integrated metropolitan interventions (cf. Regulatory Plan of Athens 2014; Municipality of Athens 2009). It is worth noting that the role of the area as a "green space" has been further underlined by the location of defined playground areas, sport facilities, and other kinds of open-air recreation. However, the archaeological and monumental identity of the site is simultaneously strengthened by the positioning of freestanding archaeological objects from various excavations from the broader catchment area of Athens throughout the Academy park.

Despite its history, the Archaeological Park is not visited by large numbers of tourists and/or locals; it seems to function mainly as a public green space for the adjacent residential areas. Although the lack of good public transport provision and the poor connectivity with the city centre of Athens compound this situation, a more important factor is the exclusion of Plato's Academy from 


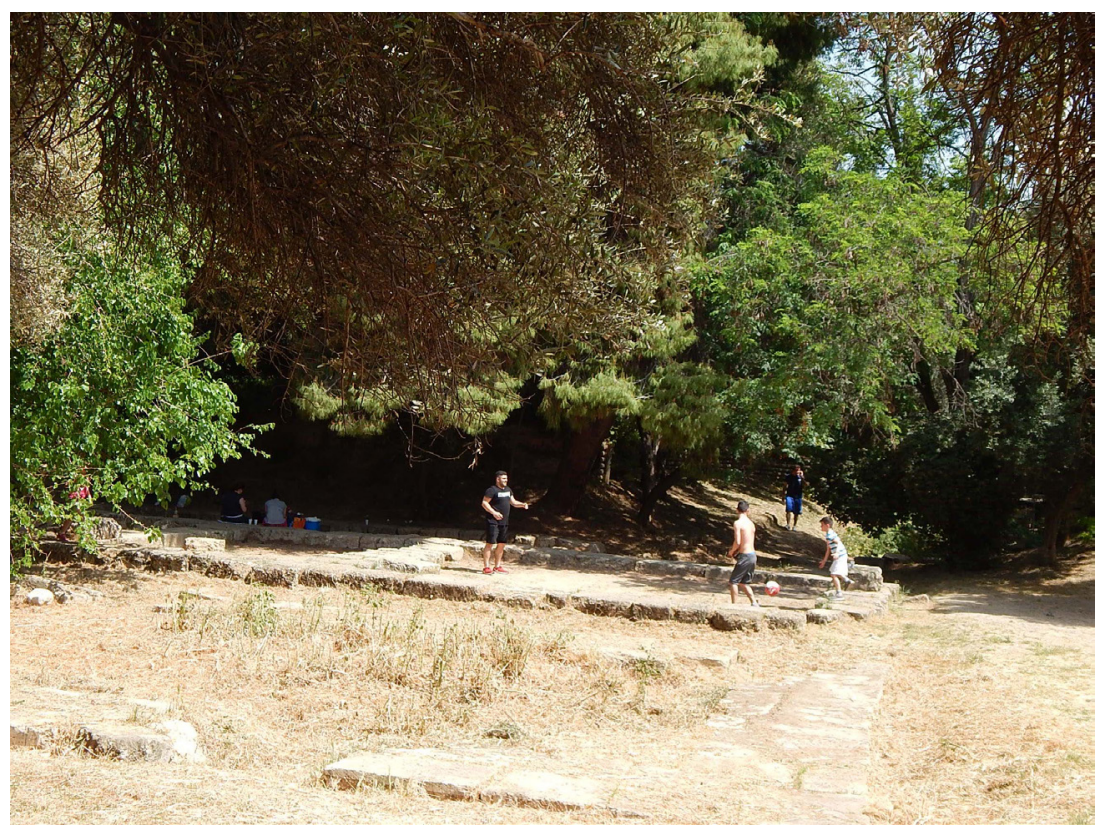

Figure 3: A way of appropriating the Gymnasium's archaeological remains in Plato's Academy Park (Source: authors).

the UPASA programme, as well as the more general delay in the realisation of the overall developmental plan discussed above. However, what makes this case study particularly noteworthy is the 'social workshop' that has been taking place in the area with direct (spatial and symbolic) reference to the archaeological site: the workshop comprises collectivities that organise discussions, activities and interventions within the boundaries of the site, relevant to a range of social, economic, political and cultural themes. At the same time, the highly engaged 'Residents Committee', as well as other local groups, stage dynamic interventions in the public dialogue about the site's use, negotiating (a) the expansion of the archaeological site's boundaries (already crowned with some success through their 2008 campaign); ${ }^{18}$ (b) the protection of the unique character of the park; (c) its upgrade and connection with the archaeological site of Kerameikos; (d) the broader regeneration of the area through an appropriate institutional framework (e.g. low building elevations, co-operative structures

${ }_{18}$ A substantial tract of private land had been acquired through public funds and subsequently incorporated into the official boundaries of the archaeological site. However, although institutional approval of this transaction has been secured, its financial fulfilment remains unresolved, endangering the overall completion of the initiative. 
for local business activities, etc.) and (e) the further enhancement of its public character through a wide array of actions and workshops (e.g. common co-operative economy, organic agriculture, permaculture etc.) (see Chazapis 2015). In general, residents and other groups are guided by a desire to protect the archaeological space because they consider it to be a 'public good'.

In summary, even though there is no official model of collaborative management of the Park, it is notable that the personnel of the local Archaeological Ephorate and the local groups enjoy a relatively smooth working relationship, exemplified by the constant presence of the resident groups within the archaeological site, where they perform a range of their initiatives and activities (See Galanos in this volume), often without the need for a 'special permit' from the authorities.

\section{Philopappos Hill}

The archaeological site of Philopappos Hill comprises three distinct hills; the Hill of the Muses, the Pnyx and the Hill of the Nymphs, forming a rocky outcrop to the west of the Acropolis. The three sites are collectively known as Philopappos Hill, with the site deriving its name from a Roman mausoleum and monument dedicated to a prince from the Kingdom of Commagene, Gaius Julius Antiochus Epiphanes Philopappos, and situated at the SW side of the Acropolis, on the Hill of the Muses.

Today, Philopappos Hill represents a collective of archaeological sites of great symbolic and environmental significance for the local population, but also a major tourist attraction (particularly on the eastern part where there are views of the Acropolis). In contrast to the archaeological park in Plato's Academy, archaeological remains in this area have been taken into account as far as the design of green spaces on the Hill is concerned. More specifically, we refer to those archaeological remnants that have been designated significant by the Ministry of Culture and the Archaeological Ephorate (e.g. the Pnyx), but also to Pikionis' work ${ }^{19}$ which is classified as a monument of modern cultural heritage. The archaeological landscape is therefore in a dialogue with the natural landscape, yet it must be emphasised that this does not apply equally to all three hills comprising Philopappos (Figure 4).

19 The work of the architect Dimitris Pikionis represents a ground-breaking intervention on the eastern side of the Philopappos Hill. Through personal effort and persistence, he created a unique landscape, which, in contrast to the norms of his time, materialises an idea of "Greekness" whereby the ancient is in dialogue with folk, modern and contemporary cultural elements as well as the natural landscape of Attica, using a broad spectrum of collages that bring together ancient spolia and neo-classical, Byzantine and traditional elements. 


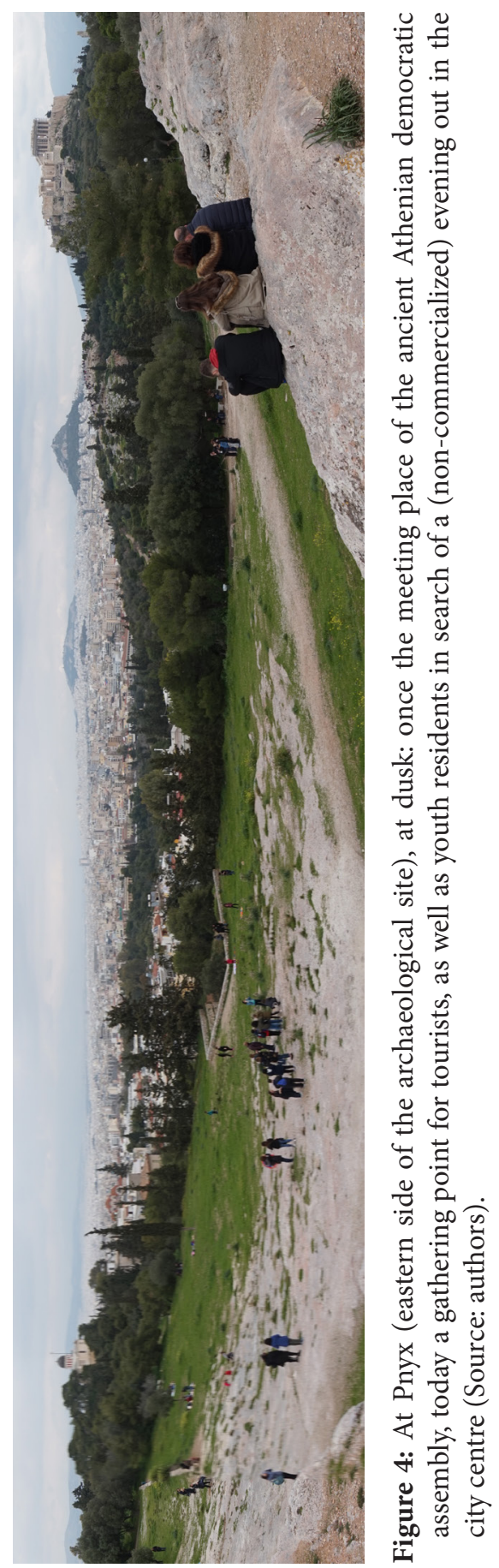




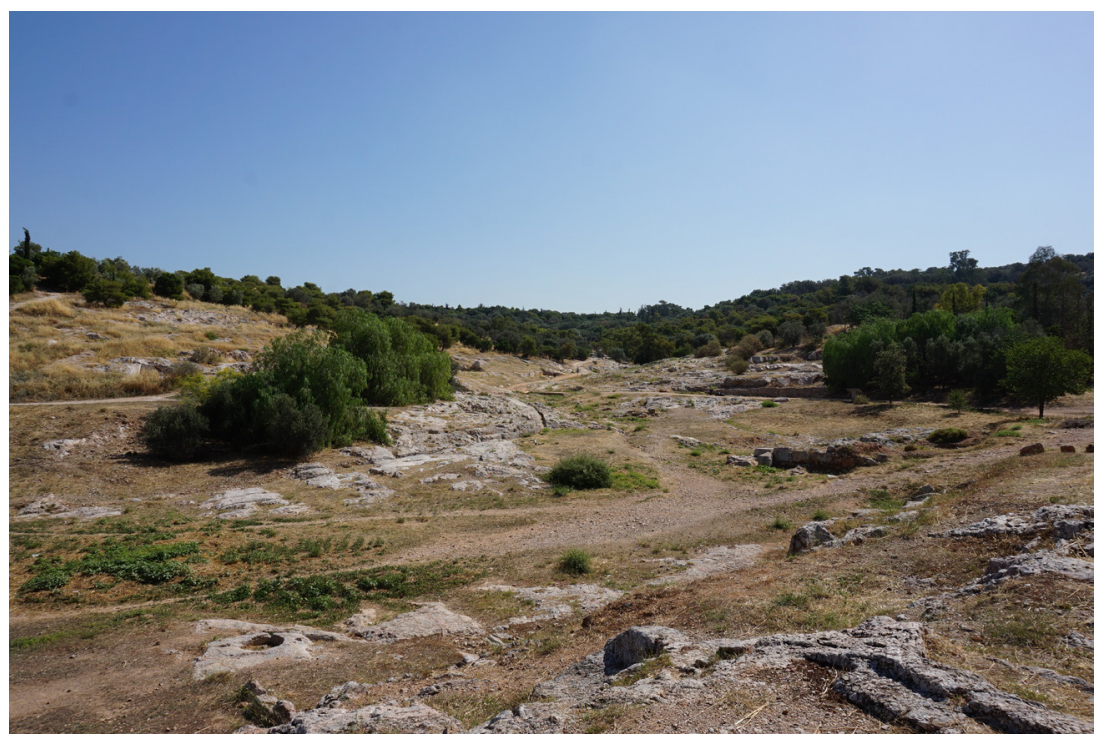

Figure 5: Experiencing the loveliness, as well as loneliness of the western part of Philopappos' Hill, while walking on the ancient commercial road travers-

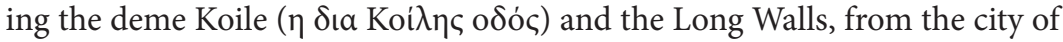
Athens to the port of Piraeus (Source: authors).

Looking briefly at the history of area, what ought be stressed is its diachronic use as an open space, its distinctiveness as a natural feature of the Athenian landscape, its multifunctional character, as well the diversity of its forms of management. During antiquity, it accommodated the demes of Melite, Kolyttos and Koile, while in early modern times, it was used as a refugee residential area extending to the outskirts of the ancient site (Figure 5). During medieval times and subsequently under Turkish rule, the hill was transformed into agricultural and pastoral land, while in the $17^{\text {th }}$ century it attracted the interest of the first European travellers to Greece. In the $19^{\text {th }}$ century it survived the damages caused to the broader area during the Greek War of Independence. 1833 was a crucial date in the recent history of the city of Athens and Philopappos Hill was no exception; this was the year when the town was officially named the capital of the newly formed Greek State. According to the prevalent historical narrative of the period, Athens was expected to express and represent a Western ideal of classical antiquity, in which the Acropolis Hill and the Parthenon constituted an absolute ideological construct that provided an official incentive for the establishment of the modern capital. Already in the first urban planning proposal for the new city a suggestion was made to keep the Philopappos area free of buildings, incorporating it into the broader archaeological space around the Acropolis. However, until the mid $20^{\text {th }}$ century, the Hill was encroached 


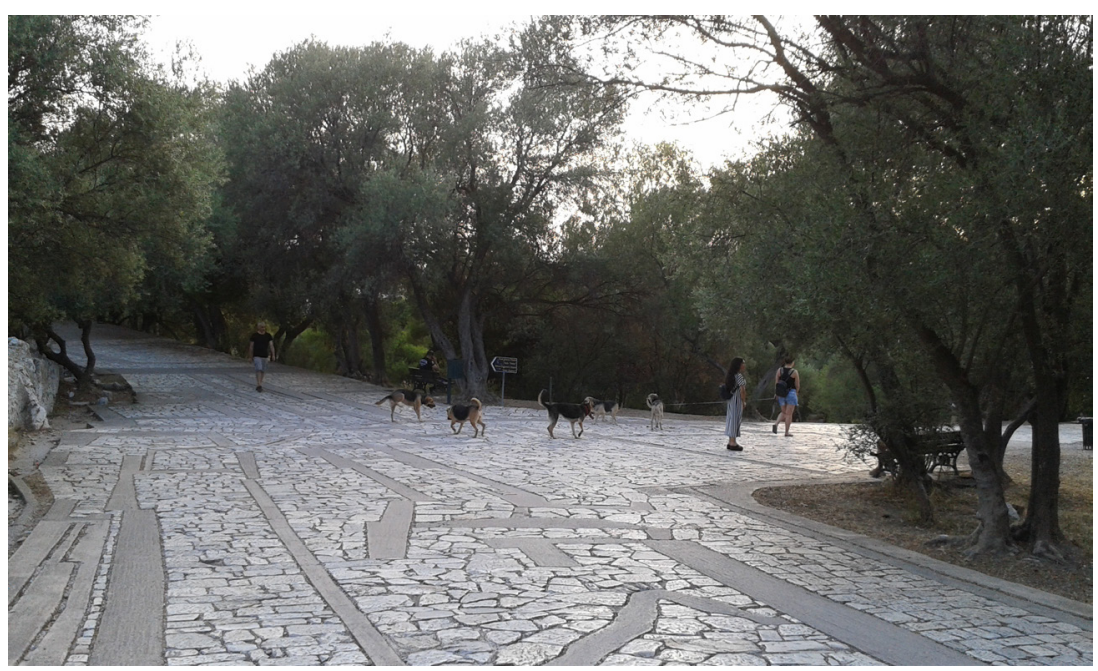

Figure 6: The daily walk of pet dogs on Philopappos' Hill (Source: authors).

upon and subjected to dangerous over-mining, the marks of which are still visible today. Also, even though large building projects have taken place in the area, a large part of the Hill was spared and protected largely due to extensive projects of reforestation since 1900. Lately (1997-2004), the area formed part of the Unification Programme of the Archaeological Sites of Athens (UPASA) (Dakoura-Voyatzoglou 2013; Noukakis et al. 1998).

Today, the residents of neighbourhoods situated close to the Hill (such as Koukaki, Petralona), as well as other sociopolitical groups, strive to defend the public character of the area - against the demands and acts of trespassing by private actors - and to safeguard the cultural landscape and its function as an open green space. ${ }^{20}$ Despite a firm official proposal to introduce controlled, albeit free, access to the site, currently the Hill remains accessible on a 24-hour basis (Figure 6). In fact, this was the explicit aim of a legal campaign mounted by the residents' committee which had a ground-breaking positive result in a decision by the Supreme Court in 2015: ${ }^{21}$

"...in the case of the movement against the enclosure of the Philopappos Hill in Athens, we could assume that the incentives for taking action were linked with practices developed in relation to the hill, such

${ }^{20}$ https://filopappou.wordpress.com/. Last access 20 November 2019.

${ }^{21}$ The Supreme Court decided in favour of the Residents' request to keep the space accessible 24 hours (including during the night) based on the argument that the citizens have a constitutional right to access and enjoy public cultural spaces and that the counter-arguments for the enclosure of the hill were not adequately supported by evidence. 
as spatiotemporal patterns of roaming, but also related to memories, experiences and general representations of the Philopappos Hill as an open space. The practice of taking action thus can be considered as an important aspect in the daily routine of the neighbourhood, even if expressed differently for each person" (Chaidopoulou-Vrychea 2016: 95).

Up until today, local residents' demands do not seem to be directed towards models of exclusive participatory management and/or cooperative governance; or to be more precise, these have not been made known as such in any official way. Instead the main concern of the residents appears to be the protection and improvement of the existing green area. ${ }^{22}$ It is for precisely this reason that they frequently instigate planting initiatives as well as other gardening upkeep activities (e.g. watering, pruning of the existing vegetation etc.). However, quite often the lack of dialogue and collaboration between the various local collectivities and the central authorities leads to unilateral actions on both sides which result in and keep feeding tensions and confrontation.

\section{Discussion}

What becomes readily apparent from the discussion so far is that both Philopappos Hill and Plato's Academy Park have managed to unmask deeper structural shortcomings of the hegemonic model of archaeological site management, particularly in urban contexts such as Athens. What has been the main issue at stake is the involvement of organised collectivities in decision making as far as both planning and daily experience of these spaces are concerned. The Hill and the Archaeological Park represent clear manifestations of sharing and participation, setting themselves apart from the ownership and enclosure models of the past that the Archaeological Service has long envisaged and advocated. Equally interesting, however, is the fact that the situation as it currently stands does not seem to call for a radical reconfiguration of their governance, since on several occasions operational aspects have existed that continue to be resolved with recourse to existing administrative structures, often with the support of local communities. This implies that perhaps the shift from enclosure to openness in archaeological sites such as Philopappos hill and the Academy Park necessitates a shift towards a more evolved framework of collective, multi-level, multi-stakeholder governance.

${ }^{22}$ In December 2008, following an official request by the hill's Residents Committee, a group of scientists conducted a specialised inquiry on the condition of the vegetation on the Philopappos Hill. Their scientific report outlined the poor state of the plant material on the hill and urged for its immediate regeneration. For details see: https://filopappou.wordpress .com/2008/12/12/1-3/. Last access 20 November 2019. 
But what exactly would collective governance of urban heritage entail? The first issue to take into account is the very concept of the 'collective'. Who is involved in governance, what is the degree of official/formal involvement? As Sani has recently pointed out (2015: 4), this issue is very difficult to tackle:

"If the Framework Convention on the Value of Cultural Heritage for Society opened for signature by Council of Europe Member States in 2005 at Faro, Portugal, defines a "heritage community" as consisting of "people who value specific aspects of cultural heritage which they wish within the framework of public action, to sustain and transmit to future generations", the current literature refers to a variety of other communities all of which are to be taken into account when developing participatory processes: "source communities" or "communities of origin" which are the ones from which, in the case of museums for example, collections originate; "user communities", e.g. visitors to a site or a museum, "interpretive communities" referring to the active contribution in the interpretive and meaning making process of heritage according to constructionist theories, "contemporary communities", "communities of practice" or "communities of interest" defined as "informal, self-organized network of peers with diverse skills and experience in an area of practice or profession, held together by the members' desire to help others (by sharing information) and the need to advance their own knowledge (by learning from others)"; "virtual communities" or "online communities", emerging as a result of the use of Web 2.0 where the increasing production of user generated content can in principle lead to the merging of all the above mentioned communities" (Sani 2015: 4).

The significance of the above passage lies in its demonstration, first of all of how our field of enquiry widens up enormously when referring to openness and participation. Although we could indeed associate these dynamic fluctuations with the concept of commoning discussed above, it is important to remember that heritage is not merely a value under constant negotiation, but, above all, constantly contestable. By extension, heritage not only solidifies communities, but also results in the formation of transient socio-political groupings. What we need to bear in mind from the onset, therefore, is that heritage results from, reproduces (and even) re-establishes asymmetrical and confrontational relations.

Let us consider an archaeological site in Athens: can we really take this heritage to constitute the material and symbolic resource of some local community? Cultural heritage may have a local, supra-local, national or international value. Classical antiquity may be understood as a common resource for (and by) many that do not belong to the citizen body of the Greek state. Philopappos Hill is an indicative example of multi-layered archaeological value. At the same time, the state remains the official entity that maintains the right to manage 
the archaeological heritage resources legally located within its physical borders, since heritage, apart from representing a cultural phenomenon and ultimately a universal value, remains a modernist institutional category still at work (Lekakis 2012). And of course, the modernist legacy of the current state is not the only reason why this form of management is maintained. Since participation recognizes a role for both public and private actors, the state could be seen as a regulatory mechanism operating more against the 'private' and less so against bottom-up social formations.

Following this line of argument, the regulatory role of the state may even be strengthened by bottom-up participation, in contributory or collaborative types of projects (through the creation of focus groups, the setting up of advisory groups representing different segments of the local population, the hosting of specific actions in the heritage site and/or Grassroots projects etc.). If such initiatives are context specific and adapted to particular conditions and/ or circumstances (Sani 2015: 6), overall responsibility for the area is not necessarily challenged or contested: even in the two case studies examined here, it is obvious (at least so far) that local communities mainly express demands relating to the role of the areas as open green parks and less to their role as archaeological sites. According to Tsavdaroglou's classification (2015), the situation at Philoppappos Hill and the Archaeological Park at Plato's Academy are closer to Ostrom's vision of commoning and the so-called "polycentric" system of governance (1998: 27).

A polycentric system of governance raises issues not only about the level of involvement of different communities and/or groups, but also about the very nature and character of scientific practice. To begin with, antiquities are not inexhaustible or self-regenerating resources like, for example, some types of immaterial cultural heritage. The performance of mnemonic practices is what keeps them alive and sustains them by renewing their nature and character. However, in the case of the archaeological sites protection, conservation and longevity depend on scientific know-how and interdisciplinary work (by archaeologists, conservators, architects, engineers etc.). It is reasonable therefore, to question which urban groups or organisations could adopt such a rigorous social constitution so as to allow them to also acquire the institutional mandate for the management of such complex public archaeological parks like Philopappos Hill and Plato's Academy Park, hence guaranteeing their sustainability. From this perspective, and since no local community strives for a thoroughly collective governance regime for the Hill or the Park, the interaction that takes place between local authorities and official institutions moves towards distributing roles and actions to each entity depending on its particular character and reach. These are context-specific distributions and this makes it clear once more that commoning is what mainly emerges in the urban context of heritage use, not so much as a process leading to a standardized managerial practice, but more as a negotiation between groups over a 'common issue', the 
distribution and redistribution of roles but within a dialectic spirit and commitment. This is a process that leaves issues pending and unresolved, without, however, surrendering its political stance neither to the state/closed model nor to the neoliberalist model of social fragmentation.

An equally important point to address is whether openness may operate effectively at the level of interpretation. On the one hand, the obsessive insistence of the Greek state to monumentalise all classical period ruins adds a further weight that the Philopappos Hill, for example, finds difficult to bear, with its residents paying less attention to classical antiquity monuments and more on material traces linked with lived experiences and more recent chronological periods (Plantzos 2018: 106). This is certainly important as, although the Archaeological Service prioritises certain periods (and associated materialities) in its heritage management strategy and promotion, local communities are calling for more room in our interpretations for the so-called contemporary period (or in any case the more recent past). Of course, this is not only a demand of the non-specialists; in fact, the academic world has long stressed the need to direct analytical attention to other periods and in this respect, it finds itself largely attuned with the demands and/or objections expressed by the public. What needs to be stressed, however, is that the opening up of interpretation to a wider audience (and why not the private sector itself?) entails a fundamental risk: are we really ready for any kind of interpretation? Is there really room at a site such as the Pnyx for an anti-classicist narrative of how the ancient Athenians took advantage of the Delian League treasury to finance the ambitious building programme of the Acropolis? After all, nationalist and extreme right-wing narratives revolving around classical antiquity have already proven to be very popular, especially in the years following the Greek financial crisis. How many difficult or contested narratives can such an open space sustain or even bring to the fore? And what is the role of archaeologists in this newly emerging picture?

Along with openness at the level of narrative and interpretation, there also exists openness at the level of experience. The affordances of an 'open' and 'shared' space for transformation and flexibility also need to be considered when dealing with openness: how and to what extent does a particular place enable the incorporation of different uses, functions and practices (hence groups of people) under its auspices? In this respect, sites like Philopappos Hill and the Archaeological Park at Plato's Academy, which involve several and diverse social uses, can fulfil this specific criterion. By contrast, other archaeological sites which have a more restricted operational identity lack this potential. However, it would be naïve to suggest that the communal use of a large archaeological site in a capital city like Athens, results only in positive forms of appropriation. As in many other public spaces, similarly urban monuments and archaeo-logical sites can easily be transformed into dystopias of the dense, fast shifting and impossible to contain urban reality. For instance, the overuse and abuse of antiquities are also all part of the contemporary landscape of Philopappos Hill and although everyone, from the official authorities to the local communities 
seek solutions to such problems, they do not do so in common. ${ }^{23}$ Perhaps this dichotomy in reaction stems from the fact that 'openness', 'open use' (and even 'abuse') are not that straightforward and uncontested terms. To state a simple example, openness at the level of experience, according to environmental psychology (Canter 1977; Stokols \& Altman 1987) depends on factors that determine how 'hospitable' and/or attractive a site is for different groups of people. Sound, noise, light or darkness, the ability to enjoy a view of the part or the city, to contact or set one's self apart from other people, the clear signposting of the space or the room to manoeuvre in, or intervene upon that space, changing variables like the complexity or the coherence of the space, emotional reactions or expectations (such as feelings of fear or safety) can create multiple sensory and psychological responses that alter the experience of different subjects and/ or groups and provoke highly heterogeneous social (re)actions.

Of course, all the above are also radically influenced by a new parameter concerning openness, stemming from the newly emerging condition of dwelling which combines real space with digital space. In particular, what would be analytically worthwhile to investigate in future research is, for instance, how intensely controlled and closely supervised archaeological sites and/or monuments (like the Acropolis), often inaccessible for certain groups of people (e.g. people with reduced mobility) can be transformed into a wholly open space in social media platforms, mobile apps and VR or AR virtual environments (Catapoti \& Vavouranakis 2016). Would digital presence and/or visibility be considered to fall into the category of the 'open'? And how would this affect interpretations as well as experiences of an archaeological site such as Philopappos or Plato's Academy Park?

\section{Concluding remarks}

This article has attempted to move beyond the polarized distinction between 'open' and 'closed' management models for archaeological sites and monuments, by suggesting that strategies of openness may be present in a host of different approaches ranging from resistance politics and attacks on the conventional centralised managerial systems to implicit and explicit assimilation and expansion attempts of the commercialised logic of neoliberal capitalism. The two case studies examined - Philopappos Hill and Plato's Academy Archaeological Park - empirically demonstrated that strategies and actions, deriving both from institutions and non-institutional entities, have rendered these archaeological sites relatively open, a condition that marks a clear shift

${ }^{23}$ For the lack of communication, see for example: https://www.news 247 .gr/koinonia/to-pepromeno-enos-fonoy-me-archaiofylakes-se-rolo -parkadoroy; https://insidestory.gr/article/filopappou-apofaseis-skia-enos -thanatou. Last access 20 November 2019. 
from the dominant model of archaeological site management in Greece. Within this framework, the concept of the 'commons' opens up an alternative pathway between a state-based and market-oriented system of resource management. Largely drawing upon the concept of commoning, it is argued that the processes that bring different actors, collectivities and institutions into constant negotiation over a common resource is a more advantageous way of grasping the reality that takes shape in hybrid spaces (heritage sites - public parks). It was also discussed whether the two case studies revealed practices that could lead towards a regime of closer resemblance to radical definitions of the commons. The conclusion reached was that this is not as yet the case, or perhaps even the expectation. The chapter concluded by describing the idiosyncrasies of urban archaeological heritage, which appear to play a significant role in the maintenance of a more symmetrical ('polycentric') condition in its governance.

Both the conditions of openness and of commoning, as well as the complexity of the sites examined here certainly point to the need to redefine current management models and to explore more collaborative and participatory schemes for the future. One must be careful, however, to not cancel out, but rather to amplify the dynamics and inventiveness of commoning as a constant process of becoming and reinventing the past (the sites, the materialities, memories, identities, and groups involved), as opposed to any static labelling ('state', 'private', 'top-down', 'bottom-up', including even the very concept of the 'commons').

\section{Bibliography}

Alexopoulos, G. \& Fouseki, K. (2013). Introduction: Managing archaeological sites in Greece. Conservation and Management of Archaeological Sites, 15(1), 1-12. DOI: https://doi.org/10.1179/1350503313Z.00000000043.

An Architektur (2010). Beyond markets or states: Commoning as collective practice. Public interview with Massimo de Angelis and Stavros Stavrides. An Architektur, 23, 4-27.

Anderson, P. (1998). The origins of postmodernity. London, United Kingdom: Verso.

Antoniadou, S., Vavouranakis, G., Poulios, I. \& Raouzaiou, P. (Eds.). (2018). Culture and perspective at times of crisis: State structures, private initiative, and the public character of heritage. Oxford, United Kingdom: Oxbow.

Appadurai, A. (with Chadha, A., Hodder, I., Jachman, T. \& Witmore, C.). (2008). The globalization of archaeology and heritage: A discussion with Arjun Appadurai. In G. Fairclough, R. Harrison Jnr., J. H. Jameson \& J. Schofield (Eds.), The Heritage Reader (pp. 209-218). London, United Kingdom: Routledge.

Bianchi, R. V. (2003). Place and power in tourism development: Tracing the complex articulations of community and locality. Pasos, 1(1), 13-32. 
Retrieved October 10, 2018, from http://www.pasosonline.org/Publicados /1103/PS020103.pdf.

Boissevain, J. (Ed.). (1996). Coping with tourists: European reactions to mass tourism. Oxford, United Kingdom: Berghahn.

Bollier, D. (2014). Think like a commoner: A short introduction to the life of the commons. Gabriola Island, BC.: New Society Publishers.

Buck Sutton, S. \& Stroulia, A. (2010). Archaeological sites and the chasm between past and present. In A. Stroulia \& S. Buck Sutton (Eds.), Archaeology in situ: Sites, archaeology, and communities in Greece (pp. 3-50). Plymouth, United Kingdom: Lexington Books.

Caffentzis, G. (2005). Dr Sachs, Live8 and neoliberalism's 'Plan B'. In D. Harvie, K. Milburn, B. Trott \& D. Watts (Eds.), Shut them down!: The G8, Gleneagles 2005 and the Movement of Movements (pp. 51-60). Leeds: Dissent! \& Brooklyn, NY: Autonomedia.

Caffentzis, G. (2010). The future of 'The Commons': Neoliberalism's 'Plan B' or the original disaccumulation of capital? New Formations, 69 (Summer), 23-41. DOI: https://doi.org/10.3898/NEWF.69.01.2010.

Canter, D. (1977). The psychology of place. London, United Kingdom: Architectural Press.

Carman, J. (2005). Against cultural property: Archaeology, heritage and ownership. London, United Kingdom: Duckworth.

Caruso, A. (2013). Akademia: Archeologia di una scuola filosofica ad Atene da Platone a Proclo (387 a.C.-485 d.C.). SATAA: Studi di Archeologia e di Topografia di Atene e dell'Attica, 6. Paestum, Italy: Pandemos.

Catapoti, D. (2013). To own or to share?: The crisis of the past at the onset of the $21^{\text {st }}$ century. In M. Relaki \& D. Catapoti (Eds.), An archaeology of land ownership (pp. 260-290). London, United Kingdom: Routledge.

Catapoti, D. \& Relaki, M. (2013). An archaeology of land ownership: Introducing the debate. In M. Relaki \& D. Catapoti (Eds.), An archaeology of land ownership (pp. 1-20). London, United Kingdom: Routledge.

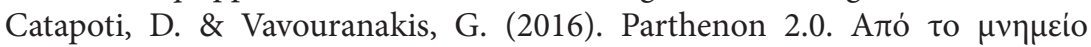

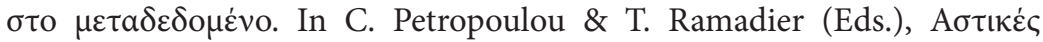

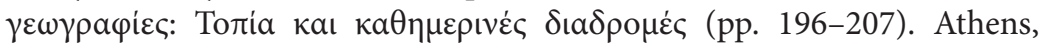
Greece: Kappon Publications.

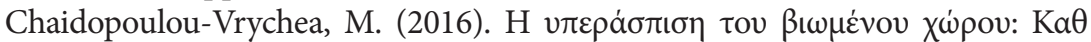

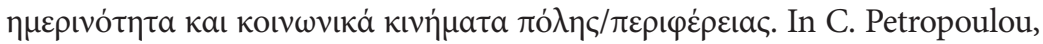
A. Vitopoulou \& C. Tsavdaroglou (Eds.), Urban and regional social movements (pp. 94-104). Thessaloniki, Greece: Research Group 'Invisible Cities'.

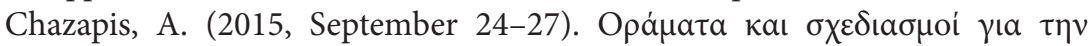

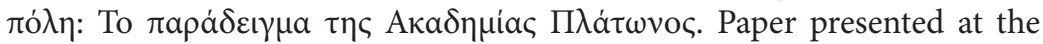
$4^{\text {th }}$ National Conference of Urban Planning and Regional Development, Department of Planning and Regional Development, School of Engineering, University of Thessaly, Volos.

Coase, R. (1960). The problem of social cost. The Journal of Law and Economics, $3,1-44$. 


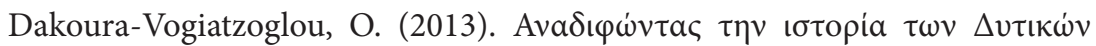

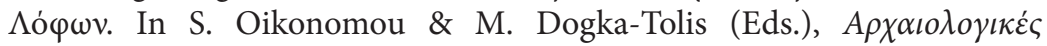

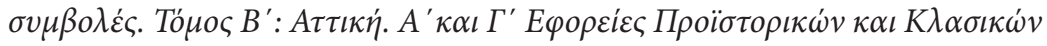
A $\chi \alpha \iota$ $\tau \dot{\tau} \tau \omega \nu$ (pp. 193-212). Athens, Greece: Museum of Cycladic Art.

De Angelis, M. (2007). The beginning of history: Value struggles and global capital. London, United Kingdom: Pluto Press.

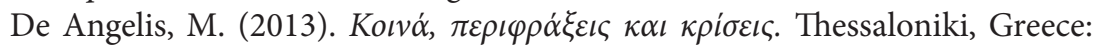
Ekdoseis ton xenon.

De Angelis, M. \& Harvie, D. (2014). The commons. In M. Parker, G. Cheney, V. Fournier \& C. Land (Eds.), The Routledge companion to alternative organizations (pp. 280-294). Abingdon, United Kingdom: Routledge.

Dellenbaugh, M. \& Schwegmann, M. (2017). Actors of urban change from an urban commons perspective. Actors of urban change: Urban Commons, Urban Change Talk Newspaper, 3, 15-17. Retrieved August 30, 2018, from https://marydellenbaugh.files.wordpress.com/2017/06/actors-of-urban -change-from-an-urban-commons-perspective.pdf.

Díaz-Andreu, M. \& Champion, T. (Eds.). (1996). Nationalism and archaeology in Europe. London, United Kingdom: University College London Press.

Dietler, M. (1994). 'Our ancestors the Gauls': Archaeology, ethnic nationalism and the manipulation of Celtic identity in modern Europe. American Anthropologist, 96(3), 584-605.

Federici, S. (2010). Feminism and the politics of the commons in an era of primitive accumulation. In C. Hughes, S. Peace \& K. Van Meter - for the Team Colors Collective (Eds.), Uses of a whirlwind: Movement, movements, and contemporary radical currents in the United States (pp. 283-293). Edinburgh, United Kingdom: AK Press.

Fotiadis, M. (2010). There is a blue elephant in the room: From state institutions to citizen indifference. In A. Stroulia \& S.Buck Sutton (Eds.), Archaeology in situ: Sites, archaeology, and communities in Greece (pp. 447-456). Plymouth, United Kingdom: Lexington Books.

Frank, S. (2015). Urban commons and urban heritage: Input for the urban heritage seminar series, University of Gothenburg, 23 ${ }^{\text {rd }}$ August 2013. In H. Benesch, F. Hammami, I. Holmberg \& E. Uzer (Eds.), Heritage as common(s) - Common(s) as heritage (pp. 19-29). Gothenburg, Sweden: Makadam.

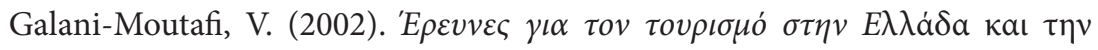

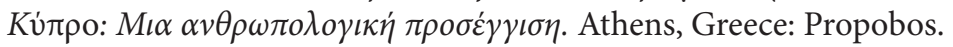

Gero, J. (n.d.). The history of World Archaeological Congress. Retrieved October 10, 2018, from http://www.worldarchaeologicalcongress.org/about -wac/history/146-history-wac.

Hall, S. (2008). Whose heritage?: Un-settling 'the heritage', re-imagining the post-nation. In G. Fairclough, R. Harrison Jnr., J. H. Jameson \& J. Schofield (Eds.), The Heritage Reader (pp. 219-228). London, United Kingdom: Routledge. 
Hamilakis, Y. (2007). The nation and its ruins: Antiquity, archaeology, and national imagination in Greece. Oxford, United Kingdom: Oxford University Press.

Hamilakis, Y. \& Duke, P. (Eds.). (2007). Archaeology and capitalism: From ethics to politics. Walnut Creek, CA: Left Coast Press.

Hardt, M. \& Negri, A. (2009). Commonwealth. Cambridge, MA: Belknap Press.

Harvey, D. (1989). The condition of postmodernity: An enquiry into the origins of cultural change. Cambridge, MA: Blackwell.

Harvey, D. (2011). The future of the commons. Radical History Review, 109, 101-107. DOI: https://doi.org/10.1215/01636545-2010-017.

Harvey, D. (2012). Rebel cities: From the right to the city to the urban revolution. London, United Kingdom: Verso.

Holtorf, C. (2005). From Stonehenge to Las Vegas: Archaeology as popular culture. Walnut Creek, CA: AltaMira Press.

Jameson, F. (1984). Postmodernism, or the cultural logic of late capitalism. New Left Review, I(146), 53-92.

Jumbe, C. B. L. (2006). Short commentary on "The name change; or what happened to the P?", authored by Charlotte Hess and Ruth Meinzen-Dick. Commons Digest, 2, 5-6.

Kärrholm, M. (2015). On 'crowd space' as urban commons-some notes on responsivity and the transformation of an urban square. In $\mathrm{H}$. Benesch, F. Hammami, I. Holmberg \& E. Uzer, Heritage as common(s) - Common(s) as heritage (pp. 53-62). Gothenburg, Sweden: Makadam.

Kehoe, A. B. (2007). Archaeology within marketing capitalism. In Y. Hamilakis \& P.Duke (Eds.), Archaeology and Capitalism: From ethics to politics (pp. 169-178). Walnut Creek, CA: Left Coast Press.

Kornberger, M. \& Borch, C. (2015). Introduction: Urban commons. In C. Borch \& M. Kornberger (Eds.), Urban commons: Rethinking the city (pp. 1-21). London, United Kingdom: Routledge.

Layton, R. (Ed.). (1989). Conflict in the archaeology of living traditions. One World Archaeology. London, United Kingdom: Routledge.

Law 3028/2002. On the protection of antiquities and cultural heritage in general. Retrieved November 20, 2019, from https:/www.bsa.ac.uk/wp-content /uploads/2018/11/Archaeological-Law-3028-2002.pdf.

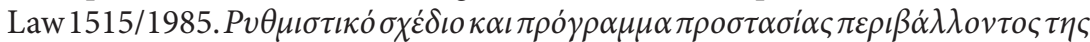

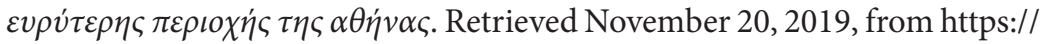
www.e-nomothesia.gr/kat-periballon/skhedia-poleon/n-1515-1985.html.

Lefebvre, H. (1991). The Production of Space. Oxford, United Kingdom: Blackwell.

Lekakis, St. (2012). The cultural property debate. In T. J. Smith \& D. Plantzos (Eds.), A Companion to Greek Art, Vol. I (pp. 683-697). Malden, MA: Wiley-Blackwell.

Leontis, A. (1995). Topographies of Hellenism: Mapping the homeland. Ithaca, NY: Cornell University Press. 
Loukaki, A. (2008). Living ruins, value conflicts. Aldershot, United Kingdom: Ashgate.

Lowenthal, D. (1985). The past is a foreign country. Cambridge, United Kingdom: Cambridge University Press.

Lowenthal, D. (2002). The past as a theme park. In T. Young, \& R. Riley (Eds.), Theme park landscapes: Antecedents and variants (pp. 11-23). Washington, DC: Dumbarton Oaks Press.

Lynch, K. (1960). The image of the city. Cambridge, MA: The MIT Press.

McNeal, R. A. (1991). Archaeology and the destruction of the later Athenian acropolis. Antiquity, 65(246), 49-63. DOI: https://doi.org/10.1017/S000 3598X00079291.

Miller, D., Rowlands, M. \& Tilley, C. (Eds.). (1989). Domination and resistance. London, United Kingdom: Unwin Hyman.

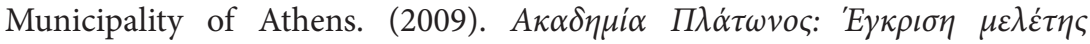

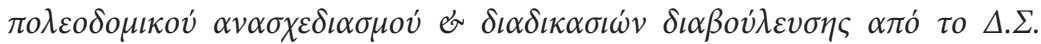
Retrieved October 10, 2018, from http://www.cityofathens.gr/node/9806.

Nicholas, G. \& Hollowell, J. (2007). Ethical challenges to a postcolonial archaeology: The legacy of scientific colonialism. In Y. Hamilakis \& P. Duke (Eds.), Archaeology and capitalism: From ethics to politics (pp. 59-82). Walnut Creek, CA: Left Coast Press.

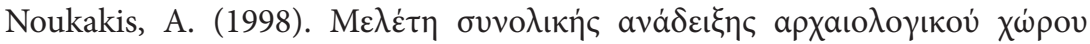

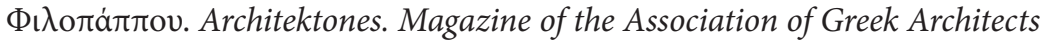
/Syllogos Architektonon Diplomatouchon Anotaton Scholon-Panellinia Enosi Architektonon (SADAS-PEA), 12/B(November-December), 41-43.

Olsen, B. (2012). Symmetrical archaeology. In I. Hodder (Ed.), Archaeological theory today (2 $2^{\text {nd }}$ ed.) (pp. 208-228). Cambridge, United Kingdom: Polity Press.

Ostrom, E. (1990). Governing the commons: The evolution of institutions for collective action. Cambridge, United Kingdom: Cambridge University Press.

Ostrom, E. (1998). Coping with tragedies of the commons. Retrieved October 10, 2018, from https://pdfs.semanticscholar.org/7c6e/92906bcf0e590e6541 eaa41ad0cd92e13671.pdf.

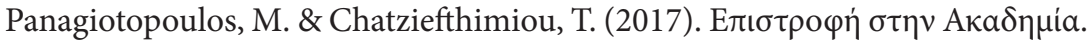
Archaiologia kai Technes, 123, 58-77.

Parker, P. \& Johansson, M. (2011, June 23-25). The uses and abuses of Elinor Ostrom's concept of commons in urban theorizing. Paper presented at International Conference of the European Urban Research Association (EURA) 2011, Cities without Limits, Copenhagen. Retrieved October 10, 2018, http://muep.mau.se/handle/2043/12212.

Pels, P. (1997). The anthropology of colonialism: Culture, history and the emergenceof Western governmentality. Annual Review of Anthropology, 26, 163-183. DOI: https://doi.org/10.1146/annurev.anthro.26.1.163.

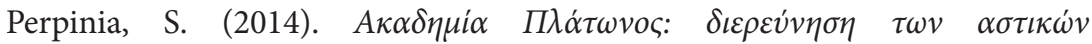

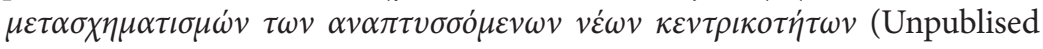


Master's Thesis). National Technical University of Athens. Athens. Retrieved October 10, 2018, from http://www.arch.ntua.gr/project/10998.

Plantzos, D. (2011). Behold the raking geison: The new Acropolis Museum and its context-free archaeologies. Antiquity, 85(328), 613-625. DOI: https:// doi.org/10.1017/S0003598X00068009.

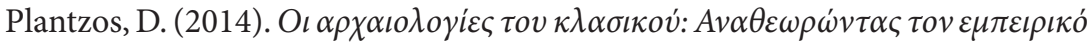
$\kappa \alpha v o ́ v \alpha$. Athens, Greece: Ekdoseis tou Eikostou Protou.

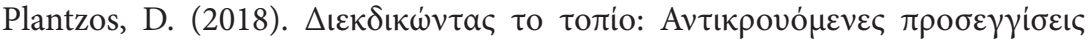

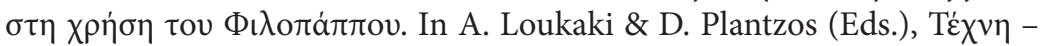

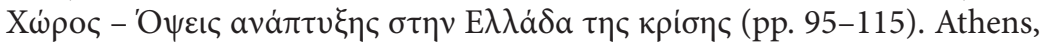
Greece: Leimon.

Sack, R. D. (1986). Human territoriality: Its theory and history. Cambridge, United Kingdom: Cambridge University Press.

Sani, M. (2015). Participatory governance of cultural heritage. Retrieved October 10, 2018, from http://www.interarts.net/descargas/interarts2538.pdf.

Shennan, S. J. (Ed.). (1989). Archaeological approaches to cultural identity. London, United Kingdom: Unwin Hyman.

Silberman, N. A. (2007). 'Sustainable' heritage?: Public archaeological interpretationand the marketed past. In Y. Hamilakis \& P. Duke (Eds.), Archaeology and capitalism: From ethics to politics (pp. 179-194). Walnut Creek, CA: Left Coast Press.

Silverman, H. (Ed.). (2011). Contested cultural heritage: Religion, nationalism, erasure, and exclusion in a global world. New York, NY: Springer Publications.

Simmel, G. (1971). The metropolis of modern life. In G. Simmel (Author) \& D.N. Levine (Ed. \& Writer of introduction), Georg Simmel on individuality and social forms: Selected writings (pp. 324-339). Chicago, IL: University of Chicago Press.

Smith, L. (2004). Archaeological theory and the politics of cultural heritage. London, United Kingdom: Routledge.

Smith, L. (2008). Towards a theoretical framework for archaeological heritage management. In G. Fairclough, R. Harrison Jnr, J. H. Jameson. \& J. Schofield (Eds.), The Heritage Reader (pp. 62-74). London, United Kingdom: Routledge.

Stavrides, S. (2016). Common space: The city as commons. London, United Kingdom: Zed Books.

Stokols, D. \& Altman, I. (Eds.) (1987). Handbook of environmental psychology. New York, NY: John Wiley \& Sons.

Thomas, J. (2004). Archaeology and modernity. London, United Kingdom: Routledge.

Tsavdaroglou, C. (2015, August 27-29). The contentious common space in Greece: From the neoliberal austerity to the SYRIZA left government. Paper presented at the RC21 International Conference on "The Ideal City: between myth and reality. Representations, policies, contradictions and 
challenges for tomorrow's urban life" Urbino (Italy). Retrieved October 10, 2018, from https://www.rc21.org/en/wp-content/uploads/2014/12/E10 .2-Tsavdaroglou.pdf.

Tziotas, C. E. M. (2015). The effects of the economic crisis on the cultural heritage of Greece: An Analysis of the EU funding (National Strategic Reference Framework) provided for the Region of Central Macedonia. Unpublished Master's Thesis. The University of Oslo, Oslo.

Urry, J. (1990). The tourist gaze: Leisure and travel in contemporary societies. London, United Kingdom: Sage Publications.

Vavouranakis, G. (2018). Archaeological resource management in Greece: State, private, public and common. In S. Antoniadou, G. Vavouranakis, I. Poulios \& P. Raouzaiou (Eds.), Culture and perspective at times of crisis: State structures, private initiative and the public character of heritage (pp. 21-39). Oxford, United Kingdom: Oxbow.

Walsh, K. (1992). The representation of the past: Museums and heritage in the postmodern world. London, United Kingdom: Routledge.

White, H. (1973). Metahistory: The historical imagination of nineteenth-century Europe. Baltimore, MA: Johns Hopkins University Press.

Wirth, L. (1938). Urbanism as a way of life. American Journal of Sociology, 44(1), 1-24.

Wylie, A. (2005). The promise and perils of an ethic of stewardship. In L. Meskell \& P. Pels(Eds.), Embedding ethics: Shifting boundaries of the anthropological profession. (pp. 47-68). Oxford, United Kingdom: Berg.

Yalouri, E. (2001). The Acropolis: Global fame, local claim. Oxford, United Kingdom: Berg.

Zarkia, C. (1996). Philoxenia receiving tourists -but not guests- on a Greek island. In J. Boissevain (Ed.), Coping with tourists: European reactions to mass tourism (pp. 143-173). Providence, RI: Berghahn Books. 